\section{Black Plastic Tarps Advance Organic Reduced Tillage II: Impact on Weeds and Beet Yield}

\author{
Haley Rylander \\ Horticulture Section, School of Integrative Plant Science, Cornell University, \\ 135 Plant Science Building, Ithaca, NY 14853
}

Anusuya Rangarajan

Horticulture, Cornell University, 15 G Plant Science Building, Ithaca, NY 14853

\author{
Ryan M. Maher \\ Horticulture Section, School of Integrative Plant Science, Cornell University, \\ 135 Plant Science Building, Ithaca, NY 14853
}

\author{
Mark G. Hutton and Nicholas W. Rowley \\ University of Maine School of Food and Agriculture and University of Maine \\ Cooperative Extension, Highmoor Farm, P.O. Box 179, Monmouth, ME \\ 04259
}

\begin{abstract}
Margaret T. McGrath and Zachary F. Sexton
Plant Pathology and Plant-Microbe Biology Section, School of Integrative Plant Science, Cornell University, Long Island Horticultural Research and Extension Center, 3059 Sound Avenue, Riverhead, NY 11901
\end{abstract}

Additional index words. polyethylene, Beta vulagris, black tarps, silage tarps

\begin{abstract}
Organic vegetable farmers rely on intensive tillage to control weeds, incorporate amendments and residues, and prepare seedbeds. Intensive tillage, however, can lead to a decrease in long-term soil health. Placing opaque plastic tarps on the soil surface weeks or months before planting can reduce weed pressure and may facilitate organic reduced tillage strategies, but few studies have documented tarp effects on crop productivity. The effect of tarp duration and tillage intensity on weeds and beet crop yields (cultivar Boro) was evaluated at three locations (Freeville, NY; Riverhead, NY; and Monmouth, ME), for two planting dates and over 2 years (2017 and 2018), resulting in a total of 10 experiments. Tarps were applied for three durations before projected planting dates: 1) 10+ weeks (long), 2) 6 to 8 weeks (mid), and 3 ) 3 to 5 weeks (short), then compared with an untarped control (none). Three levels of tillage intensity were applied after tarp removal: 1) 10 to $20 \mathrm{~cm}$ (conventional till), 2) 3 to $8 \mathrm{~cm}$ (reduced till), and 3) left undisturbed (no till), to understand interactions between tillage intensity and tarping. Tarp use of three or more weeks lowered weed biomass for several weeks after beet planting and at-harvest across most locations and years, but tarp duration beyond 3 weeks did not result in further reductions. Tarp use lowered at-harvest weed biomass and increased crop yield for reduced- and no-till systems with results similar to conventionaltill. Tarping for 3 weeks could improve the viability of reduced- and no-till approaches for organic vegetable production.
\end{abstract}

Received for publication 10 Dec. 2019. Accepted for publication 16 Mar. 2020.

Published online 14 May 2020.

We thank Brian Caldwell for help with field management and equipment usage in Freeville, NY. Thank you to Bejo Seeds for the donations of beet cv. Boro seeds for all of these experiments. Supported in part by USDA-NIFA OREI Program (2014-51300-22244), USDA-NIFA Hatch Project (1004501), and a Toward Sustainability Foundation Grant (2017).

A.R. is the corresponding author. E-mail: ar47@ cornell.edu.

This is an open access article distributed under the CC BY-NC-ND license (https://creativecommons. org/licenses/by-nc-nd/4.0/).
Despite these benefits, reduced-till in organic systems often results in lower crop yields compared with organic conventionaltill systems (Halde et al., 2015; Leavitt et al., 2011), and weed management is a primary challenge constraining reduced-till adoption by organic farmers (Lowry and Brainard, 2017). Weed density and biomass are commonly higher in reduced-till systems than in conventional-till systems (Campiglia et al., 2018; Cavalaris and Gemtos, 2002; Nakamoto et al., 2006). Although conventional farmers may increase use of herbicides when reducing tillage (Buhler et al., 1994), organic farmers primarily rely on cultivation and need more alternatives for improving weed management.

Reduced-till systems can be particularly challenging for direct-seeded root crops, such as beets (Beta vulgaris L.), for which farmers often rely on a fine, residue-free seedbed for planting. Beets are also poor competitors with weeds when they first emerge, and early-season weed control is crucial for a successful crop. Sugar beet yield is often decreased in reduced-till compared with conventional-till systems (Cavalaris and Gemtos, 2002; Koch et al., 2009); however, others have documented that yields can be similar between the two tillage approaches (Van den Putte et al., 2010). To our knowledge, no studies have evaluated organic table beet performance in reduced-till systems.

The application of temporary, impermeable, black plastic tarps to the soil surface before cash crop planting is an alternative weed management strategy recently popularized (Fortier, 2014), and adopted by some organic vegetable farmers (Rylander and Raucher, 2019). Tarps are durable, opaque, $0.15-\mathrm{mm}$ (5- to 6-mil) polyethylene plastic applied to multiple crop rows at a time. Farmers can apply and remove tarps multiple times in a season and use them for several years. This practice is in contrast to wellstudied black plastic mulch films (AbuGharbieh et al., 1988), which remain in place during crop growth, and to solarization with temporary placement of transparent plastic sheets on the soil at times of intense sunlight and warm temperatures. Solarization can reduce weed pressure and increase yields in numerous crops (Candido et al., 2011; Egley, 1983; Kanaan et al., 2018; Khan et al., 2012; Linke, 1994; Samtani et al., 2017); to be effective, soil temperatures must reach 40 to $65{ }^{\circ} \mathrm{C}$ to kill weeds, weed seeds, and other pests (Abu-Gharbieh et al., 1988; Egley, 1983; Öz, 2018).

Tarps may reduce reliance on tillage by providing a number of similar services. Tarps applied for 3 weeks suppress weeds before crop planting and create a weed-free seedbed in which to plant (Birthisel, 2018; Lounsbury et al., 2018; Rylander et al., 2020). Tarps also have the potential to promote fatal germination of some weeds by blocking light from emerged seedlings, but this may depend on other management factors, including the duration and timing of tarp use and soil disturbance before tarp application. The effect of 
tarps on weed seeds is also likely species specific. Although tarps have shown no effect on Chenopodium album L. seed germination and degradation, survival of Amaranthus powellii S. Wats. seeds in the top $1 \mathrm{~cm}$ of soil can be higher under tarped compared with untarped soil, indicating a lower germination and degradation rate under tarps (Rylander et al., 2020).

Earlier results from this experiment, presented in Rylander et al. (2020), found tarping can create a soil environment favorable for crop planting by increasing soil moisture, temperature, and soil nitrate, while decreasing weeds by $95 \%$ to $100 \%$ at planting time without soil disturbance. Three weeks of tarp duration was adequate to achieve differences compared with untarped controls. The following research investigated the effect of black plastic tarp durations on weeds and yields of a direct-seeded beet crop and compared three levels of tillage intensity after tarp removal. We hypothesized that 1) tarping would lower weed density and biomass during beet crop growth, 2) tarping would increase beet crop yield, 3) differences in tarped and untarped soils would be greatest within no-till systems, and 4) longer tarp durations would have a greater effect on these responses.

\section{Materials and Methods}

Experiments were conducted in three locations (Freeville, NY; Monmouth, ME; and Riverhead, NY) in 2017 and 2018. Untarped control treatments (none) were compared with three tarping durations: 3 to 5 weeks (short), 6 to 8 weeks (mid), or 10+ weeks (long). Tarps were applied for each duration before two target planting dates in Freeville and Monmouth, and one planting date in Riverhead. Different fields were used in 2017 and 2018. In Freeville and Monmouth, two adjacent experiments were established for each planting date in the same field, P1 and P2 (Table 1). Combining sites, years, and planting dates, we established 10 experiments overall.

Three tillage treatments were applied after tarp removal: 1) no till (planter disturbance only), 2) reduced till (3- to $8-\mathrm{cm}$ soil depth), and 3) conventional till (10- to 20$\mathrm{cm}$ soil depth). In 2018, no-till/no-tarp treatments were mowed in all locations before planting to account for only newly emerged weeds post-tarp removal in weed biomass evaluation. In all locations, beets (Beta vulgaris cv. Boro) (Bejo Seeds, Oceana, CA) were direct seeded across all treatments. In 2018, beets were thinned to a maximum of 15 plants per $31 \mathrm{~cm}$ row length $24 \mathrm{~d}$ after planting to not exceed recommended planting densities. Beets were not thinned in 2017.

\section{Experimental design}

Freeville, NY. Research was conducted in a certified organic field at the Cornell University Homer C. Thompson Vegetable Research Farm in Freeville, NY (42.523204, -76.326472) in well-drained Howard gravelly loam soil (loamy-skeletal, mixed, active, mesic Glossic Hapludalfs). The field was drill-seeded (Kasco KED-72 Eco-Drill, Shelbyville, IA) to oats at $112 \mathrm{~kg} \cdot \mathrm{ha}^{-1}$ on $25 \mathrm{Aug}$. 2016 and 2017. Oats were rotary mowed (2017) or flail-mowed (2018) in November before winterkill, to chop cover crop residues ahead of applying tarps.

All experiments had a randomized complete block design for treatments (tillage, tarp duration), with four replications (blocks) consisting of 12 plots each. All plots were $3.7 \times 3.7 \mathrm{~m}$ with two beds that were $1.8 \mathrm{~m}$ on center. Tarps were cut into $4.9 \times 4.9 \mathrm{~m}$ pieces to cover plot edges and secured to the soil surface using sand bags.

Tarps were applied at different times to achieve three durations (short, mid, and long) before two target planting dates of beets: mid-May (P1) and mid-June (P2) (Table 1), and compared with an untarped treatment. Three tillage practices were applied after tarp removal: no till, reduced till, and conventional till. Conventional till $(\approx 10.2 \mathrm{~cm}$ deep $)$ was achieved using a 1.8-m tiller (Maschio B 180-C; DeWitt, IA). Reduced-till soil disturbance ( $\approx 3 \mathrm{~cm}$ deep) was created using a notill drill with cutting discs and a cultipacker (Kasco KED-72; Shelbyville, IA). In 2017, no-till treatments in Freeville were not planted or cultivated due to high weed populations.

A pelletized chicken manure compost 5N-1.7P-2.5K (Kreher Family Farms, Clarence, NY) was broadcast-applied at 56 $\mathrm{kg} \cdot \mathrm{ha}^{-1}$ nitrogen to all treatments before tillage and planting. Beets were seeded at 14.6 $\mathrm{kg} \cdot \mathrm{ha}^{-1}$ for a plant population of $33 \mathrm{seeds} / \mathrm{m}$ $\left(7.2 \times 10^{5}\right.$ seeds/ha) using a vacuum seeder (Monosem MS 4-Row Planter; Edwardsville,
KS) with four rows per bed at $38 \mathrm{~cm}$ betweenrow spacing.

Beds of all treatments were cultivated between-row only at $\approx 10$ and $20 \mathrm{~d}$ after planting using a tractor cultivator (Saukville 2001 DDL; Newburg, WI) with standard beet knives (Empire USA S1122R; Cortland, NY).

Monmouth, ME. Research was conducted in a noncertified but organically managed field at the University of Maine Agricultural and Forestry Experiment Station: Highmoor Farm in Monmouth, ME (44.231993, -70.071939 ) in a Woodbridge fine sandy loam (coarse-loamy, mixed, active, mesic Aquic Dystrudepts). An oat cover crop was drill-seeded in mid-Aug. 2016 and 2017 at $112 \mathrm{~kg} \cdot \mathrm{ha}^{-1}$ with a Great Plains drill (3P605NT Salina, KS). In mid-December, oats were mechanically rolled down (2017) or flail mowed (2018). Tarps were held in place by sand bags and/or burying the edges. Plots were $3 \times 5.5 \mathrm{~m}$ encompassing three beds $1.8 \mathrm{~m}$ on center.

For all experiments, a split plot randomized complete block design was used with four replications (blocks) consisting of 12 plots each. Tarp durations were split by tillage treatment. Tarps were applied for the same durations before planting as Freeville (Table 1).

After tarp removal, tillage treatments were applied with a BCS two-wheeled walk-behind tractor (732GX11; Portland, OR) set at two depths: conventional till (15to 20-cm soil depth) and reduced till (5- to 8$\mathrm{cm}$ soil depth). Fifty-six $\mathrm{kg} \cdot \mathrm{ha}^{-1}$ of nitrogen was broadcast using Pro-Gro $5 \mathrm{~N}-1.7 \mathrm{P}-2.5 \mathrm{~K}$ fertilizer (North Country Organics, Bradford, VT) before tillage and planting. 'Boro' beets were hand-seeded at $2.5 \mathrm{~cm}$ in-row spacing with $38 \mathrm{~cm}$ between rows ( 40 seeds $/ \mathrm{m}, 1.1 \times$ $10^{6}$ seeds/ha). For no-till plots, a hoe was used to create a seeding path. There was no cultivation of weeds through the season.

Riverhead, NY. Research was conducted in a non-certified but organically managed field at the Long Island Horticultural Research and Extension Center (LIHREC) in Riverhead, NY (40.962271, -72.716471) in a Haven loam soil (coarse-loamy over sandy or sandy-skeletal, mixed, active, mesic Typic). A cover crop of organic oats $\left(89 \mathrm{~kg} \cdot \mathrm{ha}^{-1}\right)$ was drill-seeded (John Deer 450 Grain Drill, Moline, IL) mid-Sept. 2016 and 2017 after disking the field.

Table 1. Experiment dates for Freeville, NY; Monmouth, ME; and Riverhead, NY for two planting dates (P1 and P2) in 2 years: 2017 and 2018.

\begin{tabular}{|c|c|c|c|c|c|c|c|c|c|c|}
\hline & \multicolumn{4}{|c|}{ Freeville } & \multicolumn{4}{|c|}{ Monmouth } & \multirow{2}{*}{\multicolumn{2}{|c|}{ Riverhead }} \\
\hline & \multicolumn{2}{|c|}{2017} & \multicolumn{2}{|c|}{2018} & \multicolumn{2}{|c|}{2017} & \multicolumn{2}{|c|}{2018} & & \\
\hline Long-duration tarp applied & 15 Nov. & 30 Mar. & 17 Nov. & 2 Apr. & 8 Dec. & 27 Apr. & 21 Nov. & 10 Apr. & 19 Jan. & $21 \mathrm{Nov}$ \\
\hline Short-duration tarp applied & 20 Apr. & 18 May & 23 Apr. & 21 May & 3 May & 9 June & 15 May & 11 June & 2 May & 4 May \\
\hline Tarps removed & 16 May & 16 June & 14 May & 11 June & 8 June & 6 July & 5 June & 11 July & 1 June & 29 May \\
\hline Tillage applied & 23 May & 22 June & 18 May & 14 June & 8 June & 6 July & 5 June & 11 July & 2 June & 30 May \\
\hline Beets planted & 23 May & 22 June & 18 May & 15 June & 12 June & 6 July & 5 June & 14 July & 2 June & 30 May \\
\hline Beets harvested & 25 July & 15 Aug. & 18 July & 13 Aug. & 9 Aug. & 26 Sept. & 8 Aug. & 11 Sept. & 3 Aug. & 1 Aug. \\
\hline
\end{tabular}


The experimental design was a randomized complete block design for treatments (tillage, tarp duration), with four replications (blocks) consisting of eight plots each. Tarps were applied for three durations before the target planting date (Table 1). Two tillage treatments were applied: reduced till or no till. Reduced-till plots were prepared using a rototiller (King Kutter Inc., Winfield, AL) set at $\approx 5 \mathrm{~cm}$ depth. Pro-Gro $5 \mathrm{~N}-1.7 \mathrm{P}-2.5 \mathrm{~K}$ granular fertilizer (North Country Organics) was broadcast-applied to all plots at a rate of $45 \mathrm{~kg} \cdot \mathrm{ha}^{-1}$ of nitrogen before tillage. 'Boro' beets were direct-seeded using a vacuum seeder (MaterMacc MS8100, San Vito al Tagliamento, Italy) at a rate of $\approx 49$ seeds $/ \mathrm{m}$ $\left(1.1 \times 10^{6} \mathrm{seeds} / \mathrm{ha}\right)$. Drip-tape irrigation was placed in beet plots mid-June 2017 and 2018. There was no cultivation of weeds through the season.

\section{Sampling methods at all sites}

Weed assessment. Early-season weed biomass and density were assessed in 2018 (times based on location), and weed biomass at the time of beet harvest was assessed both years with times based on Table 1. Four 0.25$\mathrm{m}^{2}$ quadrats were placed over the center rows of each plot and included in-row and between-row areas. All weeds were counted, then clipped at the soil surface and weed biomass was determined by drying plant material at $60{ }^{\circ} \mathrm{C}$ for several days until constant weight, and reported on a grams per square meter basis. Weed density was reported on a plants per square meter basis.

Marketable yield assessment. At harvest, beets were collected from a 3.7-m length inner row in each plot and any attached soil was removed from roots. Whole plants (roots and tops) with a root diameter exceeding 2 $\mathrm{cm}$ and no blemishes were weighed as a measure of marketable yield.

Statistical analysis. Data from the two New York sites were analyzed as a randomized complete block design and for Maine as a split plot design with tarps as the main effect and tillage as the subplot. Data for all sites and planting dates were analyzed separately due to variance in management methods and significance of site in statistical analysis. Before running statistical analysis, all data were checked for normality of residuals to meet the assumptions of analysis of variance (ANOVA). Least-squares means were compared using ANOVA using $\mathrm{R}$ ( $\mathrm{R}$ Core Team, 2017) with tarp duration and tillage as fixed effects. Mean separation was by the Tukey-Kramer honestly significant difference test at 0.05 level of probability. For select weed biomass data, log transformation were applied before analysis to improve normality of residuals and were detransformed for presentation in the results.

\section{Results}

Early-season weeds. Overall, early season weed biomass in Freeville and Riverhead was small, less than $3 \mathrm{~g} \cdot \mathrm{m}^{-2}$ across all treatments for both planting dates in 2018 (Table 2). Weed density ranged from 17 to 236 plants $/ \mathrm{m}^{2}$ in Freeville and 0 to 71 plants/ $\mathrm{m}^{2}$ in Riverhead (Table 2). Reduced- and conventional-till treatments decreased weed biomass in all plantings for these locations, and there were fewer and smaller weeds in conventional-till compared with reducedand no-till treatments. Tarp use reduced weed biomass in Freeville P2, and both weed biomass and density in Riverhead P2 (Table 2). There was a significant interaction between tillage and tarping for weed density (Riverhead) and biomass (Freeville P2 and Riverhead), where tarps had a greater effect on weed density and biomass in no- and reduced-till treatments than in conventionaltill treatments.

Weed biomass was much greater in Monmouth, ranging from 77 to $214 \mathrm{~g} \cdot \mathrm{m}^{-2}$, and tarp use significantly reduced weed biomass ( $36 \%$ to $57 \%$ ) in P2 but not in P1 (Table 2). Tillage treatments had no effect on weed biomass in Monmouth.

At-harvest weeds. Weed biomass atharvest ranged from 72 to $864 \mathrm{~g} \cdot \mathrm{m}^{-2}$ in notarp treatments and from 26 to $374 \mathrm{~g} \cdot \mathrm{m}^{-2}$ in tarped treatments (Table 3). Tarp use significantly decreased at-harvest weed biomass in 6 of 10 experiments $(P<0.01)$, and there was a significant interaction between tarp and tillage treatments. In no-tarp treatments, conventional-till significantly reduced weed biomass up to nine times compared with notill treatments. In treatments with tarp use of any duration; however, there was no significant difference among tillage treatments (except in Monmouth P2 2018).

In 4 of 10 experiments, tarps did not decrease weed biomass, and there was no significant interaction between tarp duration and tillage. Of these four experiments, three were in Freeville, in which all measured treatments were cultivated twice during the season and data were not taken on no-till treatments in 2017.

Beet marketable yield. There was a significant interaction between tarp and tillage treatments for beet yield in four of 10 experiments (Table 4). In untarped treatments, conventional-till significantly increased yield compared with no-till (and sometimes reduced-till), but yield was similar across all tillage treatments (including no-till) when tarps were applied (Table 4). For example, in the second planting in Freeville in 2018, there was a significant interaction between tarp and tillage treatments $(P<0.01)$. When no tarp was used, yield was six times greater with conventional-till compared with reduced till and no till. In tarped treatments, there was no significant difference in yield between conventional-, reduced-, or no-till treatments.

Tarp use alone significantly increased total yield compared with untarped treatments in eight of 10 experiments, but tarp duration did not influence yield (Table 4). In contrast, conventional-till only increased yield compared with reduced or no till in four of 10 experiments (Table 4).

\section{Discussion}

One primary goal of tillage is to control weeds. As a strategy to advance reduced- and no-till production systems, it is important to understand tarp effects on weed emergence and competition with the following crop. In these studies, tarps were able to suppress weeds before planting without soil disturbance (Rylander et al., 2020). For no-till production, tarps can provide weed control similar to conventional-till both early in the season and at the time of crop harvest.

Table 2. Effect of tillage and tarp duration on early-season weed biomass $\left(\mathrm{g} \cdot \mathrm{m}^{-2}\right)$ and density (counts $\left./ \mathrm{m}^{2}\right)$ post-tarp removal for plantings 1 (P1) and 2 (P2) in 2018 at Freeville, NY; Monmouth, ME; and Riverhead, NY.

\begin{tabular}{|c|c|c|c|c|c|c|c|c|c|c|}
\hline & \multicolumn{4}{|c|}{ Freeville } & \multicolumn{4}{|c|}{ Monmouth } & & \\
\hline & \multicolumn{2}{|c|}{$\mathrm{P} 1$} & \multicolumn{2}{|c|}{$\mathrm{P} 2$} & \multicolumn{2}{|c|}{$\mathrm{P} 1$} & \multicolumn{2}{|c|}{$\mathrm{P} 2$} & \multicolumn{2}{|c|}{ Riverhead } \\
\hline \multicolumn{11}{|l|}{ Tillage } \\
\hline Reduced & $0.8 \mathrm{ab}$ & $162 a b$ & $0.4 \mathrm{~b}$ & $66 \mathrm{a}$ & 199 & - & 109 & - & $0 \mathrm{~b}$ & $32 \mathrm{~b}$ \\
\hline Conventional & $0.3 \mathrm{~b}$ & $93 \mathrm{~b}$ & $0.1 \mathrm{~b}$ & $17 \mathrm{~b}$ & 173 & - & 92 & - & - & - \\
\hline$P$ value & $* * *$ & $* * *$ & $* * *$ & $* * *$ & NS & - & NS & - & * & $* * *$ \\
\hline Tarp duration & & & & & & - & & - & & \\
\hline Mid & 0.7 & 179 & $0.2 \mathrm{~b}$ & 47 & 154 & - & $84 \mathrm{~b}$ & - & $0 \mathrm{~b}$ & $0 \mathrm{~b}$ \\
\hline Long & 0.7 & 181 & $0.2 \mathrm{~b}$ & 58 & 214 & - & $77 \mathrm{~b}$ & - & $0 \mathrm{~b}$ & $2 \mathrm{~b}$ \\
\hline$P$ value & NS & NS & $* * *$ & NS & NS & - & $* * *$ & - & ** & $* * *$ \\
\hline Interaction & NS & NS & * & NS & NS & - & NS & - & ** & $* * *$ \\
\hline
\end{tabular}

${ }^{\mathrm{z}}$ Mean separation by Tukey honestly significant difference at $P \leq 0.05$.

Ns, *,**,***Nonsignificant or significant at $P \leq 0.05,0.01$, or 0.001 , respectively. 
Table 3. Effect of tillage and tarp duration on at-harvest weed biomass $\left(\mathrm{g} \cdot \mathrm{m}^{-2}\right)$ for Plantings 1 (P1) and 2 (P2) in 2017 and 2018 at Freeville, NY; Monmouth, ME; and Riverhead, NY.

\begin{tabular}{|c|c|c|c|c|c|c|c|c|c|c|c|}
\hline \multirow[b]{3}{*}{ Tr duration } & \multirow[b]{3}{*}{$\mathrm{Tl}$} & \multicolumn{4}{|c|}{ Freeville $^{z}$} & \multicolumn{4}{|c|}{ Monmouth } & & \\
\hline & & \multicolumn{2}{|c|}{2017} & \multicolumn{2}{|c|}{2018} & \multicolumn{2}{|c|}{2017} & \multicolumn{2}{|c|}{2018} & \multicolumn{2}{|c|}{ Riverhead } \\
\hline & & $\mathrm{P} 1$ & $\mathrm{P} 2$ & $\overline{\mathrm{P} 1}$ & $\mathrm{P} 2$ & P1 & $\mathrm{P} 2$ & P1 & $\mathrm{P} 2$ & 2017 & 2018 \\
\hline \multirow[t]{4}{*}{ None } & None & - & - & 144 & $281 \mathrm{a}$ & $740 \mathrm{a}$ & $864 \mathrm{a}$ & $519 a$ & $666 \mathrm{a}$ & $571 \mathrm{a}$ & $276 \mathrm{a}$ \\
\hline & Reduced & 121 & $409 \mathrm{a}^{\mathrm{y}}$ & 134 & $253 \mathrm{a}$ & $243 \mathrm{~b}$ & $331 \mathrm{~b}$ & $95 \mathrm{~b}$ & $310 \mathrm{~b}$ & $260 \mathrm{~b}$ & $136 \mathrm{~b}$ \\
\hline & Conv & 88 & $103 \mathrm{~b}$ & 97 & $72 \mathrm{~b}$ & $82 \mathrm{c}$ & $249 \mathrm{~b}$ & $92 \mathrm{~b}$ & $328 \mathrm{~b}$ & - & - \\
\hline & $P$ value & NS & $* * *$ & NS & $*$ & $*$ & $* * *$ & $* * *$ & $* *$ & $* * *$ & $* *$ \\
\hline \multicolumn{12}{|l|}{ Short } \\
\hline & None & - & - & 95 & 84 & 113 & 330 & 69 & 168 & 215 & 163 \\
\hline & Reduced & 55 & 39 & 148 & 136 & 104 & 227 & 123 & 165 & 347 & 153 \\
\hline & Conv & 79 & 34 & 86 & 206 & 132 & 183 & 54 & 138 & - & - \\
\hline & $P$ value & NS & NS & NS & NS & NS & NS & NS & NS & NS & NS \\
\hline \multicolumn{11}{|l|}{ Mid } & 193 \\
\hline & Reduced & 62 & 37 & 117 & 183 & 85 & 122 & 138 & 101 & 219 & 170 \\
\hline & Conv & 85 & 44 & 58 & 178 & 86 & 142 & 152 & 136 & - & - \\
\hline & $P$ value & NS & NS & NS & NS & NS & NS & NS & NS & NS & NS \\
\hline \multicolumn{12}{|l|}{ Long } \\
\hline & Reduced & $\overline{80}$ & $\overline{26}$ & 132 & 223 & 181 & 209 & $\begin{array}{r}13 \\
104\end{array}$ & $374 \mathrm{a}$ & $\begin{array}{l}344 \\
289\end{array}$ & $\begin{array}{l}150 \\
160\end{array}$ \\
\hline & Conv & 95 & 46 & 87 & 262 & 132 & 61 & 121 & $260 \mathrm{ab}$ & - & - \\
\hline & $P$ value & NS & NS & NS & NS & NS & NS & NS & NS & NS & NS \\
\hline & $\operatorname{Tr}$ & NS & NS & $* * *$ & NS & $* * *$ & $* * *$ & $* * *$ & $* * *$ & $* *$ & NS \\
\hline & $\mathrm{Tl}$ & NS & NS & $*$ & $* *$ & $* * *$ & $* *$ & $* * *$ & NS & NS & NS \\
\hline & $\mathrm{Tr} \times \mathrm{Tl}$ & NS & NS & $* * *$ & NS & $* * *$ & $* * *$ & $* * *$ & $* * *$ & $* * *$ & NS \\
\hline
\end{tabular}

${ }_{\mathrm{z}}$ Treatments in Freeville, NY, were cultivated twice during the season.

${ }^{\text {y}}$ Mean separation by Tukey's honestly significant difference at $P \leq 0.05$.

NS, $* * *, * * *$ Nonsignificant or significant at $P \leq 0.05,0.01$, or 0.001 , respectively.

Conv $=$ conventional; $\mathrm{Tl}=$ till; $\mathrm{Tr}=$ tarp.

Table 4. Effect of tillage and tarp duration on fresh beet weight (roots and tops) in $\mathrm{kg} \cdot \mathrm{m}^{-2}$ for plantings 1 (P1) and 2 (P2) in 2017 and 2018 at Freeville, NY; Monmouth, ME; and Riverhead, NY.

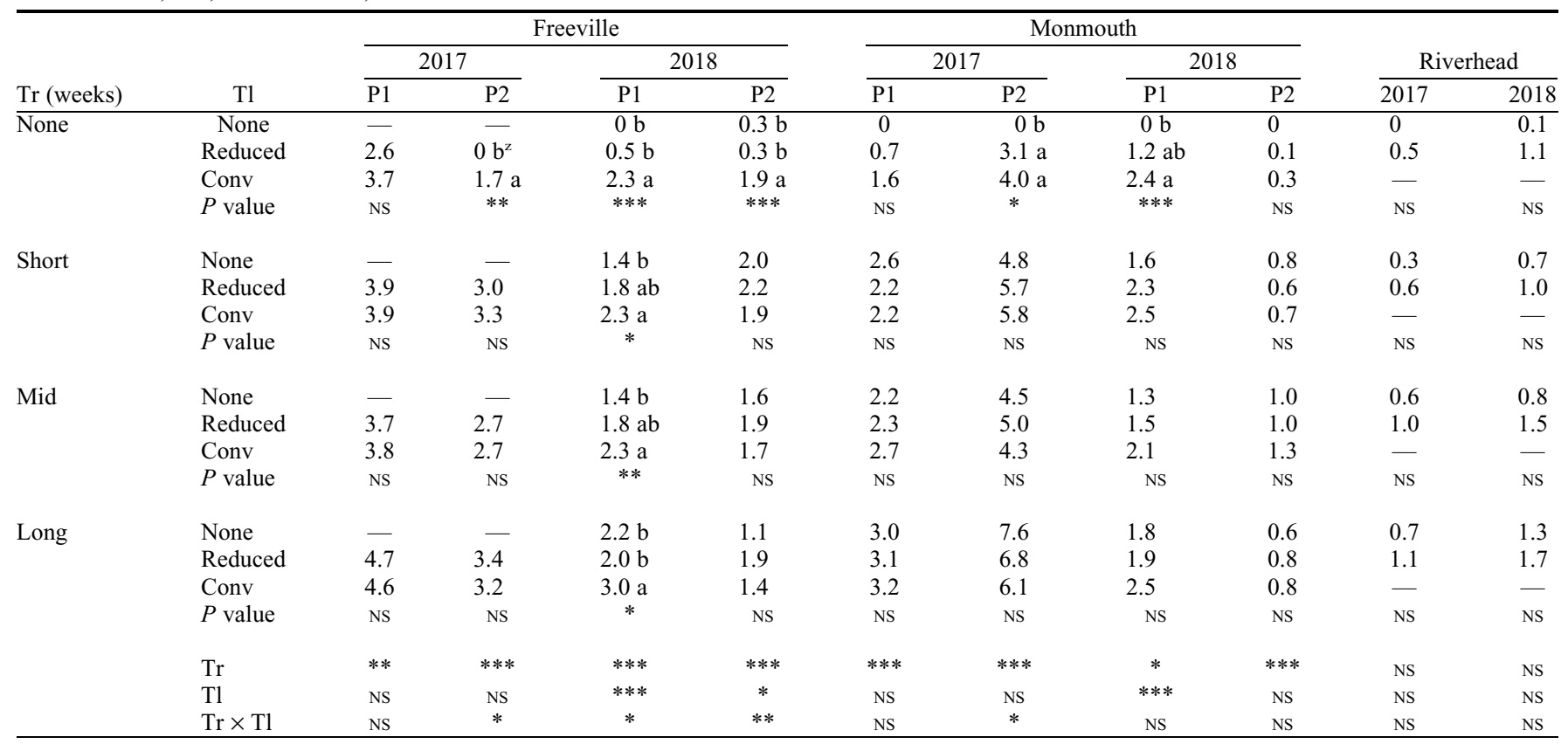

${ }^{\mathrm{z}}$ Mean separation by Tukey honestly significant difference at $P \leq 0.05$.

NS, *,**,***Nonsignificant or significant at $P \leq 0.05,0.01$, or 0.001 , respectively.

$\mathrm{Conv}=$ conventional; $\mathrm{Tl}=\mathrm{till} ; \mathrm{Tr}=$ tarp.

At the time of tarp application for early planting dates (P1) in Freeville and Monmouth (Table 1), no summer annual weeds had emerged for any treatment (Rylander et al., 2020), and cool soil temperatures likely delayed germination and emergence until after tarp removal. Most summer annuals in the northeastern United States germinate as soon as the soil warms (May or June), which was the time of tarp removal for the first beet planting in Freeville and Monmouth. By extending the early season weed-free period, tarps support improved germination conditions for direct-seeded crops like beets. For P2, short duration tarps were laid over emerged early-season weeds, primarily the winter annual, Stellaria media L., killing them before tarp removal. This suppression of winter annuals likely contributed to a decrease in early-season weed biomass.

In these experimental locations, nitrate concentrations were higher under tarps compared with uncovered soil at tarp removal (Rylander et al., 2020). Small-seeded weed 
species are generally responsive to increases in soil nutrients, such as nitrate, potentially breaking dormancy and germinating (Benech-Arnold et al., 2000). Tarps did not, however, increase the seed germination or degradation of two small-seeded weed species, C. album and A. powellii (Rylander et al., 2020). It is unknown what effect tarps would have on germination of other weed species.

The most abundant early-season weed species across locations were $S$. media, Amaranthus spp., C. album, Digitaria spp., Portulaca oleracea L., and Veronica persica Poir. The most abundant weed species at harvest were summer annuals, such as Amaranthus spp., C. album, and annual grasses in Freeville and Monmouth, and Rorippa palustris L., Matricaria discoidea DC., and Cerastium spp. in Riverhead. For these weeds, there was no advantage to tarping longer than 3 weeks. Some perennials, such as Cyperus esculentus L., Plantago major L., Rumex spp., and Taraxacum officinale L., were present in small numbers in both tarped and untarped plots, but the effect of tarps on perennial weed species is unknown.

Tarps can help facilitate reduced- and notill systems by improving weed control through the time of harvest. When reducedtill and no-till treatments were paired with tarp use, at-harvest weed pressure was comparable to conventional-till treatments with no tarp. In a New Hampshire study, tarps decreased weed biomass at harvest but had a significant interaction with roller-crimper date (Lounsbury et al., 2018). Specific tarpweed interactions may vary by region and farm, depending on climactic conditions, weed community, tillage method, and presence of cover crop residue.

Beet yield in no-till and reduced-till treatments was comparable to that of conventionaltill treatments when tarps were used (Table 4). There was a significant correlation between yield and weed biomass at-harvest $\left(R^{2}=0.2\right.$ $0.6, P<0.01$ ), and tarp suppression of weeds supported increased yields in all treatments, and similar yields among no-, reduced-, and conventional-till treatments.

Cover crop residue in tarped no-till plots did not significantly interfere with planting operations or crop establishment, likely because planting occurred 5 or more months after the termination of the oat cover crop, and residues had begun to break down. Living weeds in untarped no-till plots were likely a primary factor in decreasing crop establishment, contributing to lower stand counts and yields in these treatments.

Crop yield also may have been affected by nitrate concentrations in the soil. Soil nitrate concentrations were up to 21 times higher in tarped treatments than in untarped treatments at the time of tarp removal (Rylander et al., 2020). There was a significant positive correlation between soil nitrate concentrations at tarp removal and beet yield in six of eight experiments where nitrate was sampled $\left(R^{2}=\right.$ $0.3-0.8, P<0.05)$. Plots were fertilized with nitrogen before planting, which may have masked any yield and at-harvest weed biomass differences caused by tarping effects on soil nitrate alone. The effect of increased soil nitrate concentrations in tarped treatments on yield and at-harvest weed biomass is not clear. It is possible that tarp use could decrease weeds at planting, but higher nitrate concentrations in mid- and long-duration tarp treatments could increase the growth of weeds that germinate after tarping.

\section{Conclusions}

Tarp use of 3 or more weeks may facilitate reduced tillage in organic vegetable systems by suppressing early-season weeds and increasing crop yield. Tarps retained lower weed pressure several weeks after tarp removal, decreasing competition during the critical first few weeks of beet growth. Beet yield increased in all tarped treatments compared with untarped treatments, likely due to increased weed suppression.

Tarp use decreased the difference among no-till, reduced-till, and conventional-till treatments for both at-harvest weed biomass and crop yield. This suggests that farmers could use tarps within conservation tillage strategies in organic vegetable systems and obtain comparable yields in reduced-till and no-till systems as in conventional-till systems. Increasing tarp duration more than 3 weeks did not have a significant effect on weed suppression or beet yield. Farmers therefore retain more flexibility in their farm management plans by using tarps for shorter periods of time. Using tarps before planting a cash crop can help control early-season weeds and reduce the number of tillage passes before planting.

Further research on the effects of tillage before tarping and the response of different crop and weed species to tarping would further our understanding of how tarps can be effectively used in organic vegetable cropping systems.

\section{Literature Cited}

Abu-Gharbieh, W.I., H. Saleh, and H. Abu-Blan. 1988. Use of black plastic for soil solarization and post-plant mulching. FAO Plant Production and Protection Paper 109. Plant Protection Dept., Faculty of Agr., Univ. of Jordan, Amman, Jordan. Arshad, M.A., A.J. Franzluebbers, and R.H. Azooz. 1999. Components of surface soil structure under conventional and no-tillage in northwestern Canada. Soil Tillage Res. 53:41-47.

Beare, M.H., S. Hu, D.C. Coleman, and P.F. Hendrix. 1997. Influences of mycelial fungi on soil aggregation and organic matter storage in conventional and no-tillage soils. Appl. Soil Ecol. 5(3):211-219.

Benech-Arnold, R.L., R.A. Sa Ânchez, F. Forcella, B.C. Kruk, and C.M. Ghersa. 2000. Environmental control of dormancy in weed seed banks in soil. Field Crops Res. 67:105-122.

Birthisel, S.K. 2018. Multi-tactic ecological weed management in a changing climate. Univ. of Maine, Orono, PhD Diss. 2928.

Buhler, D.D., D.E. Stoltenberg, and R.L. Becker. 1994. Perennial weed populations after 14 years of variable tillage and cropping practices. Weed Sci. 42:205-209.
Campiglia, E., E. Radicetti, and R. Mancinelli. 2018. Floristic composition and species diversity of weed community after 10 years of different cropping systems and soil tillage in a Mediterranean environment. Weed Res. 58:273-283.

Candido, V., D. Castronuovo, V. Miccolis, and T. D'Addabbo. 2011. Weed control and yield response of soil solarization with different plastic films in lettuce. Scientia Hort. 130:491497.

Cavalaris, C.K. and T.A. Gemtos. 2002. Evaluation of four conservation tillage methods in the sugar beet crop. CIGR J. Sci. Res. Dev. 4:1-24.

Egley, G.H. 1983. Weed seed and seedling reductions by soil solarization with transparent polyethylene. Weed Sci. 31:404-409.

Fortier, J.-M. 2014. The market gardener: A successful grower's handbook for small-scale organic farming. New Society Publishers, Gabriola Island, $\mathrm{BC}, \mathrm{Canada}$.

Franzluebbers, A.J. 2002. Water infiltration and soil structure related to organic matter and its stratification with depth. Soil Tillage Res. 66:197-205.

Gupta, V.V.S.R. and J.J. Germida. 1988. Distribution of microbial biomass and its activity in different soil aggregate size classes as affected by cultivation. Soil Biol. Biochem. 20(6):777786.

Halde, C., K.C. Bamford, and M.H. Entz. 2015. crop agronomic performance under a six-year continuous organic no-till system and other tilled and conventionally-managed systems in the Northern Great Plains of Canada. Agr. Ecosyst. Environ. 213:121-130.

Hungria, M., J.C. Franchini, O. Brandão-Junior, G. Kaschuk, and R.A. Souza. 2009. Soil microbial activity and crop sustainability in a long-term experiment with three soil-tillage and two croprotation systems. Appl. Soil Ecol. 42(3):288296.

Kanaan, H., S. Frenk, M. Raviv, S. Medina, and D. Minz. 2018. Long and short term effects of solarization on soil microbiome and agricultural production. Appl. Soil Ecol. 124:54-61.

Khan, M.A., R. Khan, H. Khan, H.U. Shah, K.B. Marwat, A. Amin, and A. Nawaz. 2012. Soil solarization: An organic weed-management approach in cauliflower. Commun. Soil Sci. Plant Anal. 43(13): 1847-1860.

Koch, H.-J., B. Märländer, A. Büchse, and J. Dieckmann. 2009. Yield decrease in sugar beet caused by reduced tillage and direct drilling. Eur. J. Agron. 30(2):101-109.

Leavitt, M.J., C.C. Sheaffer, D.L. Wyse, and D.L. Allan. 2011. Rolled winter rye and hairy vetch cover crops lower weed density but reduce vegetable yields in no-tillage organic production. HortScience 46:387-395.

Linke, K.H. 1994. Effects of soil solarization on arable weeds under Mediterranean conditions: Control, lack of response or stimulation. Crop Prot. 13(2):115-120.

Lounsbury, N.P., N.D. Warren, S.D. Wolfe, and R.G. Smith. 2018. Investigating tarps to facilitate organic no-till cabbage production with high-residue cover crops. Renewable Ag. Food Systems. p. 1-7.

Lowry, C.J. and D.C. Brainard. 2017. Organic farmer perceptions of reduced tillage: A Michigan farmer survey. Renew. Agr. Food Syst. 34(2):103-115.

Nakamoto, T., J. Yamagishi, and F. Miura. 2006. Effect of reduced tillage on weeds and soil organisms in winter wheat and summer maize cropping on humic andosols in central Japan. Soil Tillage Res. 85(1-2):94-106. 
Mendoza, R.B., T.G. Franti, J.W. Doran, T.O. Powers, and C.W. Zanner. 2008. Tillage effects on soil quality indicators and nematode abundance in loessial soil under long-term notill production. Commun. Soil Sci. Plant Anal. 39:2169-2190.

Öz, H. 2018. A new approach to soil solarization: Addition of biochar to the effect of soil temperature and quality and yield parameters of lettuce (Lactuca sativa L. Duna). Scientia Hort. 228:153-161.

Power, J.F., W.W. Wilhelm, and J.W. Doran. 1986. Crop residue effects on soil environment and dryland maize and soya bean production. Soil Tillage Res. 8:101-111.
R Core Team. 2017. R: A language and environment for statistical computing. R Foundation for Statistical Computing, Vienna, Austria. $<$ https://R-project.org/>.

Rylander, H.R. and K. Raucher. 2019. Tarping: Combining Freeville research with local farm experience. Small Farms Q Spring:1011.

Rylander, H.R., A. Rangarajan, R.M. Maher, M.G. Hutton, N.W. Rowley, M.T. McGrath, and Z.F. Sexton. 2020. Black plastic tarps advance organic reduced tillage I: Impacts on soils, weed seed survival, and crop residue. HortScience 55:819-825.
Samtani, J.B., J. Derr, M.A. Conway, and R.D. Flanagan, III. 2017. Evaluating soil solarization for weed control and strawberry (Fragaria xananassa) yield in annual plasticulture production. Weed Technol. 31:455-463.

Tebrügge, F. and R.-A. Düring. 1999. Reducing tillage intensity: A review of results from a long-term study in Germany. Soil Tillage Res. 53:15-28.

Van den Putte, A., G. Govers, J. Diels, K. Gillijns, and M. Demuzere. 2010. Assessing the effect of soil tillage on crop growth: A metaregression analysis on European crop yields under conservation agriculture. Eur. J. Agron. 33:231-241. 